\title{
連続式溶融亜鉛めつきの気体絞り制御機構に関する検討*
}

\author{
安谷屋 武 志**. 阿 部 雅 樹** \\ 庄司政 浩***. 矢 野秀 勝***
}

\section{Study on Gas Wiping Mechanism for Continuous Galvanizing Line}

\author{
Takeshi AdaniyA, Masaki ABE
}

Masahiro SHōjI, and Hidekatsu YANO

\begin{abstract}
Synopsis:
The relations between coating weight and control factors are investigated quantitatively in order to clear the mechanism of the gas wiping process. A fundamental equation model proposed from an analysis of the results is as follows :
\end{abstract}

where,

$$
W=K_{0} P-K_{1} D^{K_{2}} V^{K_{3}} \exp \left(\frac{K_{4}}{V}\right)
$$

$$
\begin{aligned}
& W: \text { coating weight }\left(\mathrm{g} / \mathrm{m}^{2} \cdot \text { both sides }\right) \\
& P: \text { gas pressure at nozzle header }\left(\mathrm{kg} / \mathrm{cm}^{2} \cdot \mathrm{G}\right) \\
& D: \text { distance between nozzles }(\mathrm{mm}) \\
& V: \text { line speed }(\mathrm{m} / \mathrm{min})
\end{aligned}
$$

Although coefficients vary with the working conditions, this equation gives coating weight in the range of $7 \%$ standard deviation of error for our commercial line $\left(K_{0}=0.45, K_{1}=0.63, K_{2}=0.88, K_{3}=0.50\right.$, $\left.K_{4}=8.3\right)$.

Important factors for efficiency are the gas itself and the slit gap of nozzle. For minimization of the friction loss at nozzle, the selection of low viscous gas and relative large slit gap are effective.

\section{1. 緒言}

連続式溶融亜鉛めつき設備 (Continuous Galvanizing Line : CGL) に打ける気体絞り技術の基本は昭和 40 年 前後に開発されたが，亜鉛めつき史上画期的な優れた技 術であつたため，短期間のうちに世界の主な GGL に採 用された。

気体絞り法が亜鉛めつきのなかでこのような隆盛を遂 げたのは, 従来のロール絞り法に比較して次のよらな特 長を持つていたからである. 1) 付着量の均一性に優れ る.2）薄めつき絞りが可能. 3) 高速絞りに適する. 4 ) 装置のメインテナンスおよび付着量制御が比較的容 易など.

この気体絞り法の導入により，亜鉛めつきの品質およ び作業性は大幅に向上したが，気体絞り自体のメカニズ
ム，すなわち諸因子と付着量の因果関係は亜鉛めつき技 術者のあいだでも確立して扔らず，近年に至るまで条件 設定などの操作は作業者の経験に頼る部分が多かつた。 近年，亚鉛めつき設備の高速化拉よび自動化が叫ばれる ようになり，めつき付着量に関しても効率よくかつ強力 に絞る必要性が生じたため, 気体絞りメカニズムの検討 が不可欠となつてきた。これまでに気体絞り技術に関す るいくつかの研究例1) 3)があり，一部すでに自動制御を 手がけているといら報告45) もあるが，気体の流れなど ごく基礎的な部分に対する研究例は比較的少ない.

著者らはめつき付着量を制御するのは究極的には気体 噴流の運動量であるうと推定して気体のノズル噴出流れ を考察し，これらと付着量の関係を実験により定量的に は握するとともに単純な力学的仮説を導入して気体絞り の基本式を導いた．本報では気体絞り機構を基本式の誘

* 昭和 53 年 10 月本会講演大会にて発表 昭和 54 年 10 月 15 日受付 (Received Oct. 15, 1979)

** 日本鋼管 (怢) 技術研究所福山研究所 (Fukuyama Laboratories, Technical Research Center, Nippon Kokan K. K., 1 Kokan-cho Fukuyama 720)

*** 日本鋼管 (株) 福山製鉄所 (Fukuyama Works, Nippon Kokan K. K.) 
導過程で明らかにしたが，ノズル噴流特性を左右するガ ス体そのものおよびスリットギャップ（ノズル開口径） は気体絞りにおいても最も重要な因子であるので, これ については更に詳しく言及した。

\section{2. 実 験 方 法}

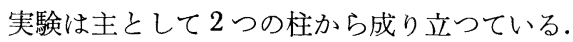

第 1 には, 気体絞り制御因子とめつき付着量との定量 的な関係をは握するため, 実際に種々の条件下でめつき 製造を行い，データを蓄積することである。この実験に 使用した設備は日本鋼管・福山 No. 1 CGL6) であり, 絞りガス体には灯油の燃焼生成ガスを用いている.

めつき量制御系の概略を Fig. 1 に示す. めつき浴を 通過した鋼帯（ラインスピードV）は表裏 1 対のノズル (ノズル間隔 D) から噴出される気体（ヘッダー部ガス生 力 $\mathrm{P}$ ）により過剰の亜鉛を絞り取られ, 所定のめつき付 着量Wを得る. 当然, 上記の汪かにも数多くの因子が考 えられるが，当初できるだけ単純化されるため他の因子 を一定にするように努めた，それらの条件を Table 1 にまとめた。 ただし，絞りガス体は気体絞り制御の 1 つ の重要な因子であり，ガス体の選択が直接その制御特性 に関係するため，過熱蒸気および空気を使用する実験も 加え別途検討した. 同様の理由でノズルのスリットギャ ップの影響についても若干の実験を行つた.

なお，実操業データを整理すると鋼帯サイズ，めつき 付着量执よび気体絞り能力の兼合いから, ラインスピー ドと要求される絞り力との間には Fig. 2 に示すような

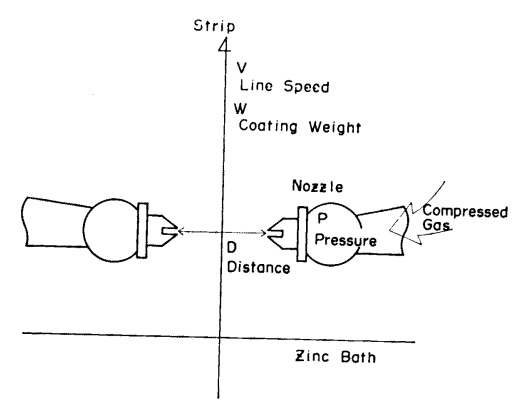

Fig. 1 Diagram of the gas wiping process.

Table 1. Working conditions in the experiment.

\begin{tabular}{c|c|c|c|c}
\hline $\begin{array}{c}\text { Nozzle height } \\
\text { above the bath } \\
(\mathrm{mm})\end{array}$ & $\begin{array}{l}\text { Nozzle } \\
\text { angle }\end{array}$ & $\begin{array}{c}\text { Gas } \\
\text { temper- } \\
\text { ature } \\
\left({ }^{\circ} \mathrm{G}\right)\end{array}$ & $\begin{array}{c}\text { Srip } \\
\text { temper- } \\
\text { ature } \\
\left({ }^{\circ} \mathrm{C}\right)\end{array}$ & $\begin{array}{c}\text { Zinc } \\
\text { temper- } \\
\text { ature } \\
\left({ }^{\circ} \mathrm{C}\right)\end{array}$ \\
\hline 200 & $\begin{array}{l}\text { horizon- } \\
\text { tal }\end{array}$ & 450 & $\begin{array}{c}400 \\
\sim 450\end{array}$ & 450 \\
\hline
\end{tabular}

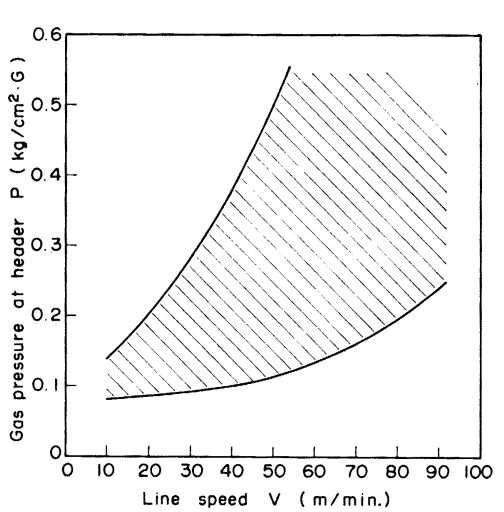

Fig. 2 Tendency of coating control for commercial line.

ある幅を持つた 1 つの傾向が存在することがわかる。た だし，本実験では気体絞り機構の全体的な特性をは握す るため，このよらな操業領域にはとらわれず，できる限 り広く制御領域をとつている.

第 2 の実験は，すでにいくつかの実験例2)7) が報告さ れているが，気体絞りノズルの動圧特性を測定すること である.めつき付着量を制御するのはめつき面に作用す るガスの運動量であると思われるが，この量がガス圧 力, ノズルからの距離 ( $\propto$ ノズル間隔)によりどのよう に表せるか，めるいはノズルのスリットギャップの大き さによつてどのような影響を受けるかなどを調査する。

ここでは実験用ノズルを用いて常温空気を種々の圧力 のもとに噴射させ，動圧をピトー管で測定した。

\section{3. 実験結果と考察}

\section{1 ガス圧カとノズル間隔}

$3 \cdot 1 \cdot 1$ 等エントロピ膨張流れ

ノズルからのガスの噴出速度は等エントロピ膨張流れ を仮定して求めることができる8)9.

ガスの圧力が臨界圧力に達しない場合, 噴出速度wは 次式で与えられる.

$$
\begin{aligned}
& w=\sqrt{\frac{2 \kappa}{\kappa-1} \frac{P}{\rho}\left[1-\left(\frac{P_{0}}{P}\right)^{\kappa-1 / \kappa}\right]} \cdots \cdots \cdots(1) \\
& \text { ここに, } P: \text { ノズルヘッダーのガス压力 } \\
& P_{0}: \text { 大気压 } \\
& \rho: \text { ノズルヘッダーのガス密度 } \\
& \kappa: \text { 比熱の比 }\left(C_{p} / C_{0}\right) \\
& \text { ヘッダー部のガス压少を増加させた場合, ノズル開ロ }
\end{aligned}
$$
部でガス圧はただちに大気圧まで減少せず, 臨界圧力 $P_{C}$ を生じるがこれは

$$
P_{\mathrm{C}}=P \cdot\left(\frac{2}{\kappa+1}\right)^{\kappa / \kappa-1}
$$




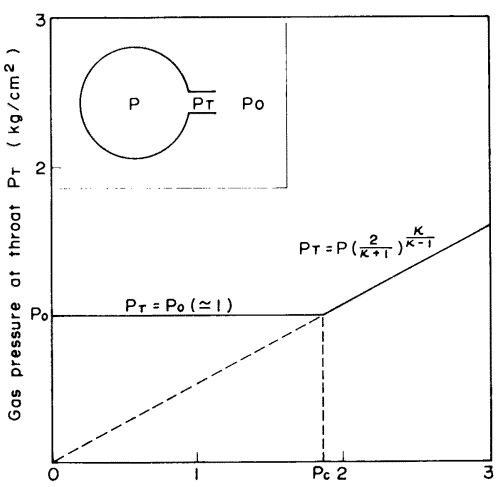

Gos pressure of heoder $P\left(\mathrm{~kg} / \mathrm{cm}^{2}\right)$

Fig. 3 Appearance of the critical pressure at nozzle (here, $P_{\mathrm{C}}$ means the pressure which causes "critical").

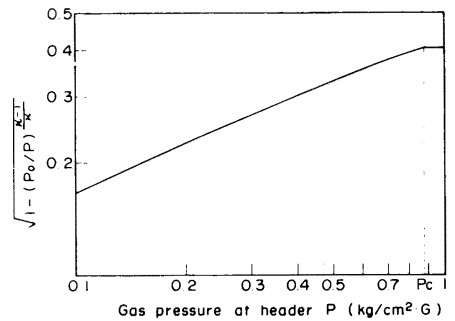

Fig. 4 Relation between $\sqrt{1-\left(P_{0} / P\right)^{\kappa-1 / \kappa}}$ and pressure at header $P$ (Gas flow rate is proportional to $P^{0.42}$ in the case of $\kappa=$ 1.4).

で与えられるので，（1)式へ代入して整理すれば，臨界 圧力時のガス噴出速度 $w_{\mathrm{C}}$ は次式となる.

$$
w_{\mathrm{C}}=\sqrt{\frac{2 \kappa}{k+1} \frac{P}{\rho}}
$$

臨界圧力に関する詳しい解説は他の記述8)9) にゆずる として，ここではヘッダー部ガス圧力 $P$ と開口部ガス压 力 $P_{\mathrm{T}}$ の関係を空気の例で Fig. 3 に示した. 空気の場 合，臨界圧力を生じるPの值はおよそ $0.886 \mathrm{~kg} / \mathrm{cm}^{2} \cdot \mathrm{G}$ である．臨界圧力以下の噴流はガス圧力一定（=大気 圧）の流れであり，Pの増加とともに流速が増加し，臨 界圧力以上の噴流は流速一定の流れで， $P$ の増加ととも に密度が増加すると考えられる。

(1) 式は空気 $(\kappa=1.4)$ を使用した場合，Fig. 4 か ら近似的に $P^{0.42}$ に比例すると考えることができる．

また噴流速度は距離 $D$ の増加とともに減衰するが， 2 次元噴流モデルを想定すると，噴流の中心速度（最大速 度) $w_{1}$ は $D^{-0.50}$ に比例することが知られている10.)これ より $w_{1}$ は簡単には $P$ と $D$ をいて次式で近似できる.

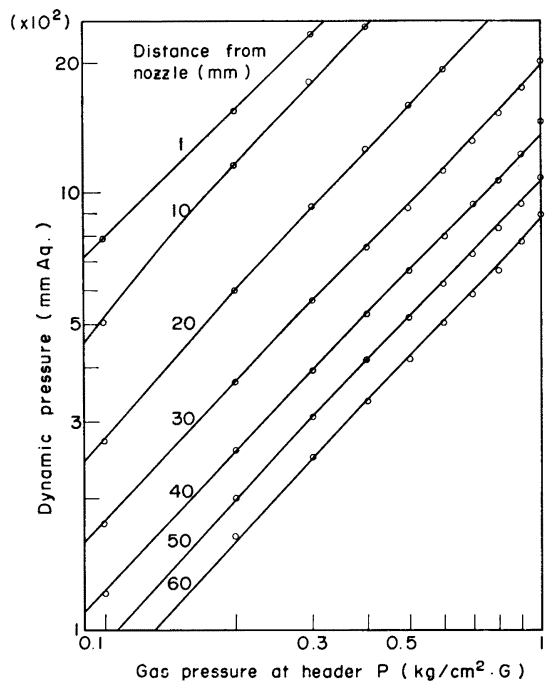

Fig. 5 Dependence of dynamic pressure on pressure $P$ for different distances from nozzle (Gas : Air, Slit gap : $1.2 \mathrm{~mm}$ ).

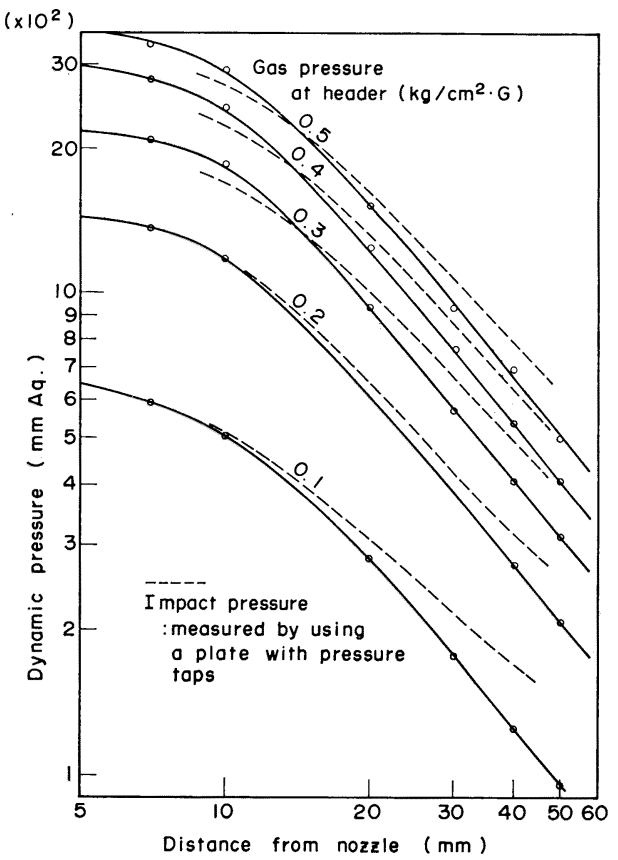

Fig. 6 Dependence of dynamic pressure on distance from nozzle for different feed pressures (Gas : Air, Slit gap : $1.2 \mathrm{~mm}$ ).

$w_{1} \propto P^{0.42} \cdot D^{-0.50}$

$3 \cdot 1 \cdot 2$ 動圧測定の結果

常温空気を使用した動圧の測定結果を Fig. 5, 6 に示 す.このようにガス圧力およびノズルからの距離と噴流 
中心部の動圧との関係はノズルに近い部分を除いて直線 化される. 直線部の傾さはガス圧力に関しては約 1.0 前後, 距離に関しては約-1.2 前後と読みとれるので, 動圧が $w_{1}^{2}$ に比例するとして次式が測定結果から導か れた。

$$
w_{1} \propto P^{0.5} \cdot D^{-0.6}
$$

(4)式と（5)式に差を生じたが，P項の差はノズル噴 出の祭の 摩擦損失が ガス圧力によつて 異なるためであ り，D項の差は大気との混合により噴流の運動量の散逸 が起きているためであろうと思われる.

図中，破線で示したのは圧力測定孔を設けた板をノズ ル前面に配置したときの測定結果である，直線の傾きが

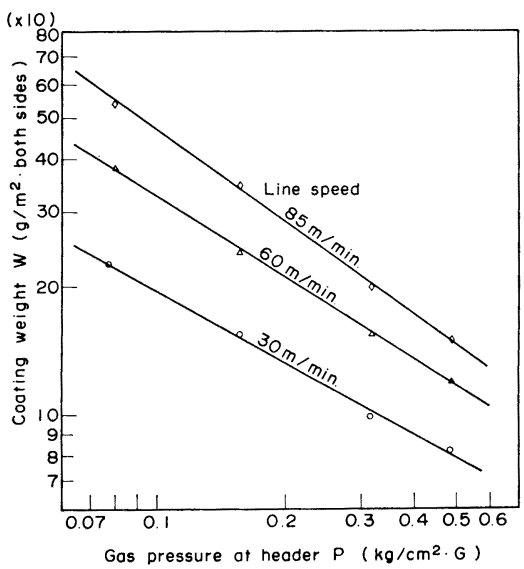

Fig. 7 Dependence of coating weight $W$ on pressure $P$ at different line speeds (Gas : Combustion products, Slit gap : $1.2 \mathrm{~mm}$, Distance between nozzles : $40 \mathrm{~mm}$ ).

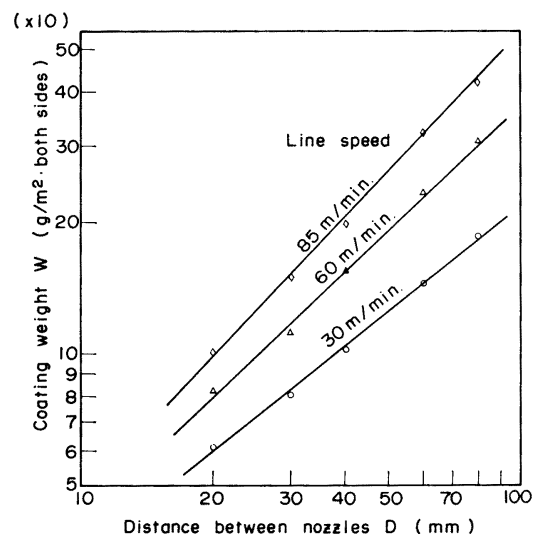

Fig. 8 Dependence of coating weight $W$ on distance $D$ at different line speeds (Gas: Combustion products, Slit gap : $1.2 \mathrm{~mm}$, Gas pressure : $\left.0.32 \mathrm{~kg} / \mathrm{cm}^{2} \cdot \mathrm{G}\right)$.
若干異なるのは板の存在による背圧および流れのよどみ の影響と推察される。

\section{$3 \cdot 1 \cdot 3$ めつき付着量との関係}

Fig. 7，8 は実ラインテスト（灯油の燃焼生成ガス使 用）の結果から得られたガス压力一付着量，ノズル間 隔一付着量の関係を㘠示したものである.それぞれの関 係はほぼ直線として近似できるが，その傾きはガス圧力

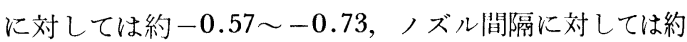
0.83〜0.96 である. 特徴的なのはラインスピードの変 化により直線の傾きが若干変化することであり，ライン スピードの増加に従つて傾きは大きくなる。これについ ての考察は後述する。

ところで既述のように付着量がガス運動量によつて決 定されると推定した場合, 付着量に関する $P$ とD指数 の比は ( 5 )式のそれと一致するはずである. 2 つの測定 結果の相違はガス体の差によるものと考えられ，補足的 に空気絞りの奏験を行つた結果から付着量が $P$ の約 -0.75 乘に比例することを確認しているので，(5) 式 との比較から付着量Wは $w_{1}$ を用いて

$$
W \propto w^{-1.5}
$$

と近似できるＦig．7，8 の結果をただちに(6)式と結 び付けるには若干無理があるが，これは年しろ，然焼生 成ガスの場合には空父と比熱の比 $\kappa$ が異なることなどに よつて噴流の速度式が（5) 式と一致しないためであると 考えられる。燃焼生成ガスを使用した動圧測定結果がな いので正確ではないが，この場合の噴流中心速度 $w_{1}^{\prime}$ は $w_{1}{ }^{\prime} \propto P^{0.43} \cdot D^{-0.60}$

と推定した.

\section{$3 \cdot 2$ ラインスピード}

ラインスピードは CGL の加熱能力で決定されてしまう ので，基本的には制御因子とは異なるものである. しか しながら付着量の制御上:，非常に 重要な 条件であるの で，これを除外しての検討はあり得ない，付着量に関係 するラインスピードの作用は以ドのようなものである.

$1)$ 亜鉛浴からの鋼帯持ち出乙亜鉛量を決定する.

2) めつき面が絞りを受ける時間を決定する.

3 ) 絞りを受ける流動亜鉛の運動量を決定する.

上記いずれの作用とも，ラインスピードの増加がめつ き付着量増につながることを示している.これらのらち 付着量制御上，最も影響力の大きいのは鋼帯の持ち出し 亜鉛量であるが，NIKOLEIZIG ら1) はこの量がラインス ピードの 0.63 乗に比例すると報告している. 本研究で も気体絞りを行わずに付着量を調查したところ，Fig. 9 に示す結果が得られ，持ち出し垔鉛量がラインスピード の約 0.5 乗に比例することを確惩した. NiKolEIZIG ら 


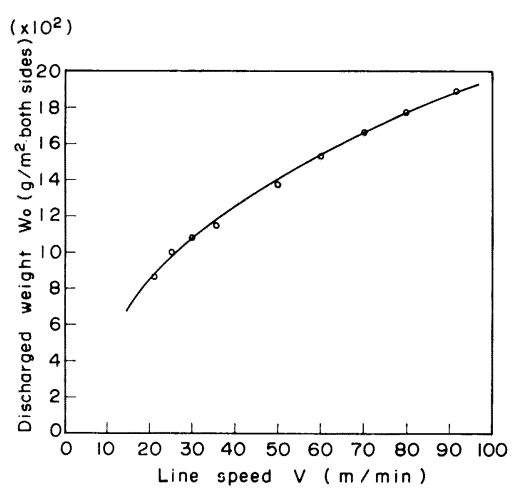

Fig. 9 Discharged zinc weight $W_{0}$ as a function of line speed $V$ without action of the jet.

の值との差はめつき浴の温度や成分，および実験範用の 差などにもよるであろうが，気体絞りを行わない場合， めつき面は平滑でなくまた浴面に浮遊している酸化亜鉛 が付着するなど䛊差要因が多いので，測定值がばらつく ことも影響していると思われる.

めつき面が絞りを受ける時間はラインスピードの逆数 に比例すると思われるが，亜鉛の運動量は比較的複雑な 因子である．亜鉛の運動量は溶融亜鉛がその粘性によつ て鋼帯に引き上げられる慣性力と自重による落下力との 差であると考えられ，浴面通過後，時間とともに減少す る、ただし，垁際には冷却による粘性の上昇なども考元 られるので，定量的に正確な判断を下すのはすずかし W.

実操業においてラインスピードの高低により，気体絞 り位置（ノズル高さ）を上下させるのはこの亜鉛運動量 変化への対処にほかならないが，本研究のためのライン テストにおいては, あえてノズル高さを一定とした。 こ れについては後述する。

\section{3 付着量モデル式}

\section{$3 \cdot 3 \cdot 1$ モデル式の誘導}

$3 \cdot 1 ， 3 \cdot 2$ では個々の 制御因子と付着量の関係につい て述べた.ここでは以上の結果をもとに基礎的な付着量 モデル式を誘導する.

めつき付着量を数式化するには大別して 2 通りの方法 が考えられる. その 1 つは気体絞りを流体力学的な手法 により解析するものであり2)，むら1つは操業データを 大型コンピュータを利用して統計解析するものである4).

著者らはこれら両方を組み合わせる手段をとることに した。 まず実験の結果得られた情報をもとに力学的な仮 定をたて，モデル式を誘導する．梅田ら²) は溶融亜鉛の 流れの状態を 2 次元の粘性流体と考え, この運動方程式
として Navier-Stokes の式を使つて亜鉛めつき厚さを 導いたが，著者らは主としてガス運動量とめつき付着量 の関係に注目し，この関係を簡単な力学的方程式で表す ことにした. 次に定数項については, 実験データを得ら れたモデル式に与えて統計的な手法によつて算出した.

以下にモデル式の誘導を示す.

めつき付着量を制御する要因は，ガスの運動量 $F$, 鋼 帯持ち出し亜鉛量 $W_{0}$, およびめつき面が絞られる時間 $t$ である.これはすなわち

$$
-d W=\frac{\partial W}{\partial F} d F+\frac{\partial W}{\partial W_{0}} d W_{0}+\frac{\partial W}{\partial t} d t \cdots \cdots
$$

で表される. ガスの運動量 $F$ を絞りに作用する量として 考えると，3.1 で述べたように，これは噴流の中心速度 $w_{1}$ で代表される動圧に相当することになる．この動压 がガス圧力 $P$ とノズル間隔 $D$ により近似的に表し得るこ と，さらに $W_{0}, t$ は $V$ によつて決定されることも既述 のと舐りなので，（7)式は

$$
\begin{gathered}
-d W=\frac{\partial W}{\partial F}\left(\frac{\partial F}{\partial P} d P+\frac{\partial F}{\partial D} d D\right) \\
+\frac{\partial W}{\partial W_{0}} \cdot \frac{\partial W_{0}}{\partial V} d V+\frac{\partial W}{\partial t} \cdot \frac{\partial t}{\partial V} d V
\end{gathered}
$$

となる。（5)，(6)式およびラインスピードに関する持 ち出し㕵鉛量などの情報を(8) 式一導入し偏微分項を整 理すると，

$$
-d W=K_{1} \frac{W}{P} d P-K_{2} \frac{W}{D} d D-K_{3} \frac{W}{V} d V-K_{4} \frac{W}{V^{2}} d V
$$

ここに $K_{1} \sim K_{4}$ は正の定数

が得られる.上式が気体絞り機構を示す方程式である. ただし，右辺第 4 項はめつき付着量の微少な減少量 $-d W$ が付着量 $W$ に比例し, 絞りを受ける時間の微少変 化分 $d t$ に比例すると仮定して導いた. さらに $P, D$, $V$ のちら，いずれか 1 つの因子の変化による付着量の変 化分 $d W$ は，その因子の変化量と付着量 $W$ につて決定 し，他の因子の状態のいかんにはよらないものとした。

(9)式を解いて付着量式を得る.

$$
\begin{aligned}
& W=K_{0} P-K_{1} D^{K_{2}} V^{K_{3}} \exp \left(-\frac{K_{4}}{V}\right) \\
& \text { ここに } K_{\mathbf{0}} \text { は正の定数 }
\end{aligned}
$$

(10) 式に灯油の燃焼生成ガスを使用してラインテスト を行つたデータを入れて，重回帰分析法により定数項を 求めた結果は以下のとおりである.

$K_{0}=0.45, K_{1}=0.63, K_{2}=0.88, K_{3}=0.50, K_{4}=$ 8.3

ただし，付着量のデータは鋼帯のセンタ一部表裏合計值 を採用した。 また使用した単位は以下である。 
Table 2. An example of the experimental data.

\begin{tabular}{c|c|c|c|c|c}
\hline $\begin{array}{c}\text { Gas pressure } \\
\text { at header } \\
\left(\mathrm{kg} / \mathrm{cm}^{2} \cdot \mathrm{G}\right)\end{array}$ & $\begin{array}{c}\text { Distance between } \\
\text { nozzles } \\
(\mathrm{mm})\end{array}$ & $\begin{array}{c}\text { Line speed } \\
(\mathrm{m} / \mathrm{min})\end{array}$ & $\begin{array}{c}\text { Measured coating } \\
\text { weight } \\
\left(\mathrm{g} / \mathrm{m}^{2} \cdot \mathrm{both} \text { sides }\right)\end{array}$ & $\begin{array}{c}\text { Calculated coating } \\
\text { weight } \\
\left(\mathrm{g} / \mathrm{m}^{2} \cdot \text { both sides }\right)\end{array}$ & $\begin{array}{c}\text { Error } \\
\left(\mathrm{g} / \mathrm{m}^{2} \cdot \mathrm{both} \mathrm{sides}\right)\end{array}$ \\
\hline 0.08 & 60 & 28 & 315 & 319 & +4 \\
0.16 & 40 & 60 & 241 & 247 & +6 \\
0.32 & 20 & 60 & 86 & 198 & -1 \\
0.32 & 40 & 85 & 199 & 217 & -12 \\
0.49 & 60 & 85 & 229 & 198 & -6 \\
0.49 & 80 & 49 & 204 & & 6 \\
\hline
\end{tabular}

Gas Combustion products, Slit gap : $1.2 \mathrm{~mm}$

Error: Calculated weight-measured weight

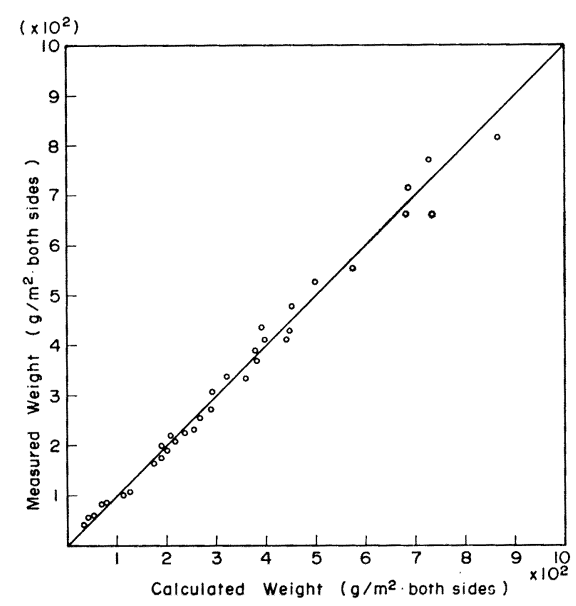

Fig. 10 Comparison of the calculated and measured coating weight (Gas : Combustion products, Slit gap : $1.2 \mathrm{~mm}$ )

$P\left[\mathrm{~kg} / \mathrm{cm}^{2} \cdot \mathrm{G}\right], \quad D[\mathrm{~mm}], \quad V[\mathrm{~m} / \mathrm{min}], \quad W\left[\mathrm{~g} / \mathrm{m}^{2}\right.$. both sides]

実験データの 1 例を Table 2 に, めつき付着量の測 定值とモデル式からの計算值の比較を Fig. 10 に示し た.上記モデル式による付着量推定值の䛊差標準偏差は 約 7\% である.

\section{$3 \cdot 3 \cdot 2$ モデル式に関する補足検討}

各製造ラインの仕様はガス体，スリットギャップなど の気体絞り制御要素から, めつき浴温度などの周辺要素 に至るまでさまざまに異なるので，本実験で得られた $K$ 值があらゆるラインに適合するものではない。しかしな がら気体絞り機構を表現するといら趣旨からいえば, (10) 式は基礎的な付着量式として十分満足できるものと 考えられる.すなわち(10)式より得られる情報は絞り機 構を理解するらえで重要である.この主なものは(8)式 から (9) 式への移行で想定した概念・紧的仮説であ る.この概念が実際のメカニズムとおおむね一致するも
のであることは誤差偏差 7\%といら実績から推定される が，その值は変動要素（たとえば鋼帯の振動など）によ るものとして片づけには大きすぎる。そこで著者らは モデル式に何か付記すべき事項がないか検討した.

最も注目されるのはラインスピードの影響である. Fig. 7，8 に見られるラインスピードによる直線の傾き の変動はモデル式誘導過程で述べた $\partial W / \partial P, \partial W / \partial D$ が $V$ によらないといら仮定をくつがえすものであるここの 現象をもら少し一般的に調べるために，(5') 式で表せ る噴流中心速度を用いて実験結果を整理した。これを Fig. 11 に示す. 図から明らかなように, ラインスピー ドにより直線の傾きは異なるが，これとは別にラインス ピード $60,85 \mathrm{~m} / \mathrm{min}$ の低ガス流速側, および $30 \mathrm{~m} /$ min の高流速側では直線からのずれが観察される. 実験 範囲の両端部に拈けるこのような非直線性は 3.2 に述 ベた亜鉛の運動量が影響しているものと思われる。すな わち, 高ラインスピード時には絞りを受ける亜鉛の運動 量は大きく, 絞りガスの運動量がそれに比較して極端に 小さい場合には十分な絞り効果が期待できないし，逆の 場合では強力な絞り力によつて亜鉛の粘土上昇（絞り限 界）が生じると考えられる。言うまでもなく $(10)$ 式は本 質的に上記のような極端な領域では成立しないものであ る.

このよらに絞りガスと絞りとられる亜鉛の両運動量の 極度の不均衡が䛊差を生み, 特に本実験ではノズル高さ を一定としたこともこれを助長していると推察する．実 操業的にはすでに Fig. 2 に示したような制御領域があ り，これは上述の論旨から言えば好ましい傾向と考えら れる.

\section{4 絞りガス体}

絞りガス体を变えた場合, 気体絞り特性がどのように 影響を受けるかは重要な問題である. 理論的には上述の モデル式の原型 $(10)$ 式は変わらないはずであるから，こ の場合には $K$ 值を修正することで対処できると考えられ る. そこで最も與味深いのはガス体による絞り力の大小 
の比較である.

Fig. 12 は常温の空気と約 $250^{\circ} \mathrm{C}$ の水蒸気（過熱蒸 気）を例にとつて絞り力の比較を試みた実験結果であ 门，同一の絞り条件のもとでは空気の方が絞り力は大き いことがわかる．単純には，大気との圧力差がそのまま 動圧（=ガスの運動量）に結び付くはずであるにもかか わらず，この絞り力の差は何に起因するのか.

このため再度，ノズルからの等ェントロピ膨張流れに 注目した．ガスの噴出速度は (1) 式で与えられ，動圧は 次式で示される.

$$
\frac{1}{2} \rho_{0} w^{2}=\rho_{0} \frac{\kappa}{\kappa-1} \frac{P}{\rho}\left[1-\left(\frac{P_{0}}{P}\right)^{\kappa-1 / \kappa}\right] \cdots \cdots
$$

ここに $\rho_{0}$ は常圧時のガス密度

$P / P_{0}=\left(\rho / \rho_{0}\right)^{\kappa} よ り$

$$
\frac{1}{2} \rho_{0} \omega^{2}=\frac{\kappa}{\kappa-1} P\left(\frac{P_{0}}{P}\right)^{1 / \kappa}\left[1-\left(\frac{P_{0}}{P}\right)^{\kappa-1 / \kappa}\right]
$$

(12)式によると動压はガス压力のみに依存することに なるので，Fig. 12 の差は“等ェントロピ”としては説 明できないことがわかる. そこで運動量損失のある流れ を想定して，このよらな流れの特性を決定する1つの要 因として流れによつて生じる粘性応力に注目すれば，こ の值の大きいほど主流中心速度の減衰が早めに起こると 推定できる.このことを蒸気噴流と空気噴流の例で比較

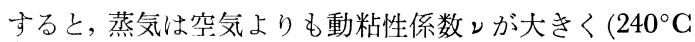

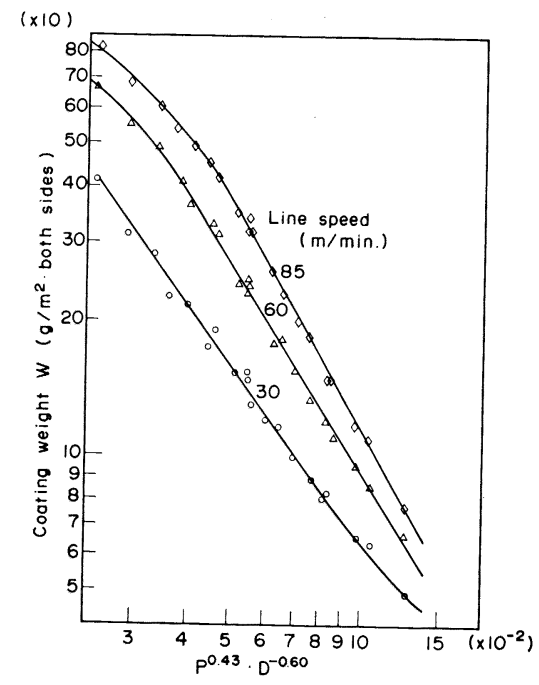

Fig. 11 Coating weight $W$ as a function of $P^{\mathbf{0 . 4 3}}$. $D^{-\mathbf{0 . 6 0}}$ which is proportional to gas flow rate (Gas : Combustion products, Slit gap : $1.2 \mathrm{~mm})$.

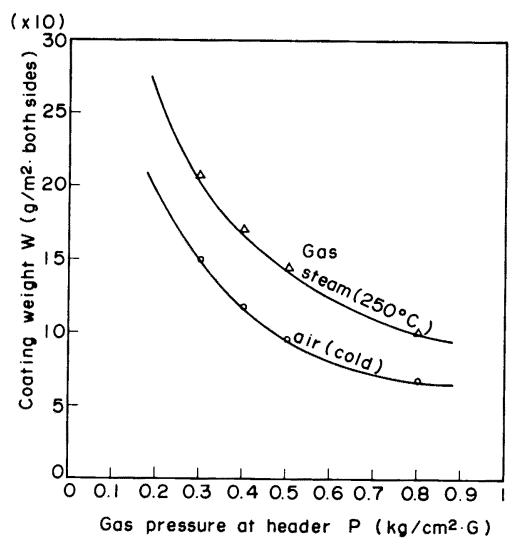

Fig. 12 Influence of the gas itself on the coating weight $W$ as a function of feed pressure $P$ (Distance between nozzles : $20 \mathrm{~mm}$, Line speed : $60 \mathrm{~m} / \mathrm{min}$, Slit gap : $0.6 \mathrm{~mm}$ ).

蒸気: $0.426 \times 10^{-4} \mathrm{~m}^{2} / \mathrm{s}, 20^{\circ} \mathrm{G}$ 空気 : $0.156 \times 10^{-4} \mathrm{~m}^{2} /$ $\left.\mathrm{s}^{11)}\right)$ ，流れを層流であると仮定した場合にはノズル開口 部での摩擦により生じる境界層（速度こう配を生じてい る部分）の厚さ $\delta$ は $\sqrt{\nu t}(t$ : 時間) に比例して増加す るので12)13), 単純な計算では境界層がンズル開口部で生 じてから噴流の中心まで達する時間は空気の場合に比較 して約 $1 / 2.7$ に短縮され, 流速の差を考慮してもこれに 相当する距離（㛜密にはノズル平行開口部入口からの距 離) は約 $1 / 1.6$ に短縮されることになる. 実際のノズル ではスリット (平行開口部) の流路力向の長さは流速に 比べて十分短いので, 噴流中心部まで摩擦の影響がおよ ぶのは大気中に噴射されたあとと推定される．開口部以 降は大気の抵抗による影響が生じるので，上述の值は厳 密には正しくないが，いずれにせよ，蒸気が空気より絞 り力に劣るといらことはその粘性の相違から理解される と思われる。

ガス体については上述のよらな絞り力の問題のほかに 品質面での問題が論じられることがある.すなわち酸化 性のガス体で絞つたとき，亜鉛めつき面を酸化させない かといらことである. 本実験では特にこのような現象は 見られなかつた，噴流は絶えず大気をまき込んでいるの で，たとえ絰素ガスのような不活性ガスを使用したとし ても, あまり大きなメりットは期待できないと想像され る. 亜鉛浴面の酸化（トップドロスの生成）についても 同様である.

\section{5 スリットギャップ}

ノズルのスリットギャップもガス体とならんで気体絞 り特性を決定する重要な因子である. 


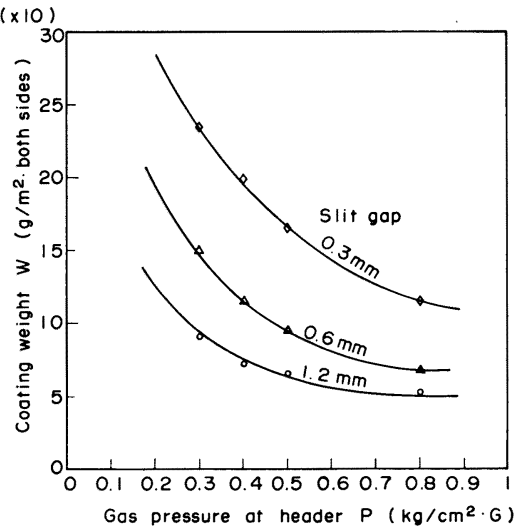

Fig. 13 Influence of the slit gap on the coating weight $W$ as a function of feed pressure $P$ (Gas : Air, Distance between nozzles : $20 \mathrm{~mm}$, Line speed : $60 \mathrm{~m} / \mathrm{min}$ ).

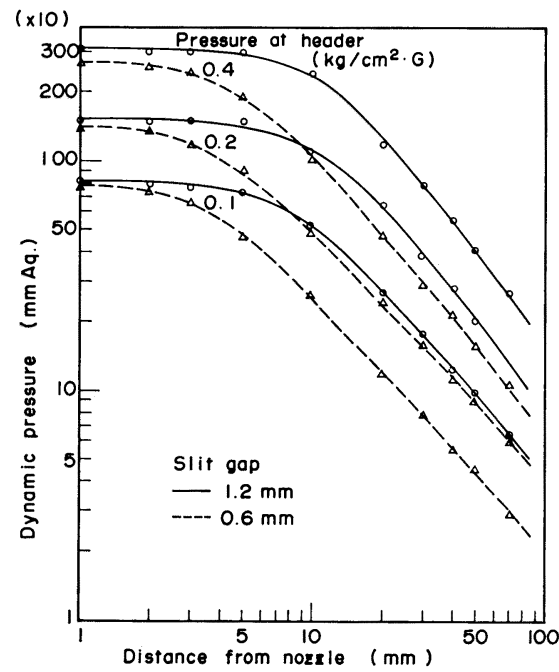

Fig. 14 Influence of the slit gap on dynamic pressure as a function of distance and pressure (Gas : Air).

Fig. 13 にスリットギャップを変更した実験例を示 す. 図より同一ガス圧力ではスリットギャップの大きい 方が絞り力は大きいことがわかり，スリットギャップが $1 / 2$ になつた場合，同じ絞り力を得るためには約 2 倍の 圧力が必要となる.この事実は Fig. 14 によつて説明で きる.Fig. 14 はFig. 13 で使用したスリットギャップ について動圧を測定したものである。両実験で使用した ガス体は常温空気である.

すでに $3 \cdot 1$ に述べたように, 直線領域に打ける傾きは スリットギャップの大小にはよらず，拉よそ 1.2 であ
る. なた $D \geqq 10$ の範囲では，スリットギャップが $1 / 2$ になつたとき，同じ動圧を得るには約 2 倍のガス圧力を 必要とする。これは動压が〔スリットギャップ】/〔距離〕 に比例するという梅田らの報告2) と定性的には一致す る.このよらにスリットギャップの差から生じる絞り力 の差は動圧（㛜密には噴流中心部の動圧）が異なること によるものと判断できるが，これらノズル形状の差によ つて動圧特性が変化することについても，摩擦抵抗の考 察により説明することができる.

スリットギャップの相違によつて生じたノズル開口部 近傍における動圧の差は, 摩擦抵抗による流れの運動量 損失分の差に相当すると考えられる. 動圧の直線的な減 少を始める位置が異なるのも, 噴流中心部へ摩擦抵抗が 影響するまでに要する時間が異なるためである.

ノズルに拈ける噴流の摩摖特性は上述のように動圧利 得と重要な相関を持つと考えられるので，著者らはさら に別の視点からも検討を試みた．Fig. 15 はノズルから のガス噴射を示す i-s 線図である. 図中，1-2 で示した のは摩擦損失のない場合の状態変化（等エントロピ変 化）であり，摩擦損失を伴う場合は 1-3 で示される. 摩 擦損失を伴う噴流の流速 $w_{\text {斤 }}$ は次式で与えられる9).

$$
\begin{gathered}
w_{\mathrm{f}}=\sqrt{\frac{2 \kappa}{\kappa-1} \frac{P}{\rho}\left[1-\left(\frac{P_{0}}{P}\right)^{n-1 / n}\right]} \\
\text { ここに } n=\kappa(1+\zeta) /(1+\kappa \zeta) \\
\zeta: \text { 摩擦損失係数 }
\end{gathered}
$$

動圧測定より得られる流速を(13) 式一代入すれば， $n$ の 值は計算され摩擦損失係数らが求まる. ガス圧力が増加 して臨界圧力に達した場合には，噴流の圧力は大気圧に

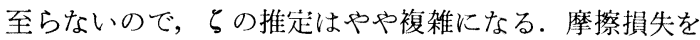
伴う場合の臨界圧力 $P_{\text {cf }}$ は

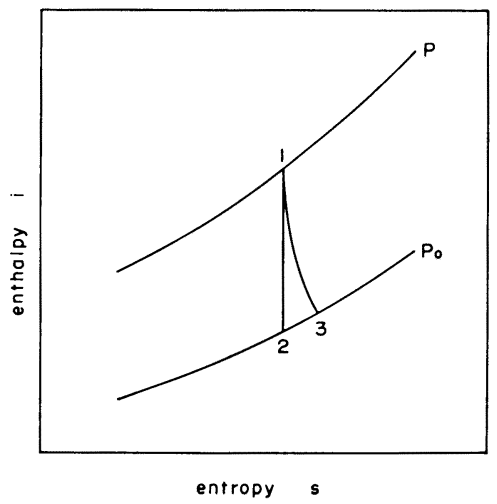

Fig. $15 i-s$ diagram for the nozzle jet $(1-3,1-$ 2 means the change with and without friction loss at nozzle respectively). 


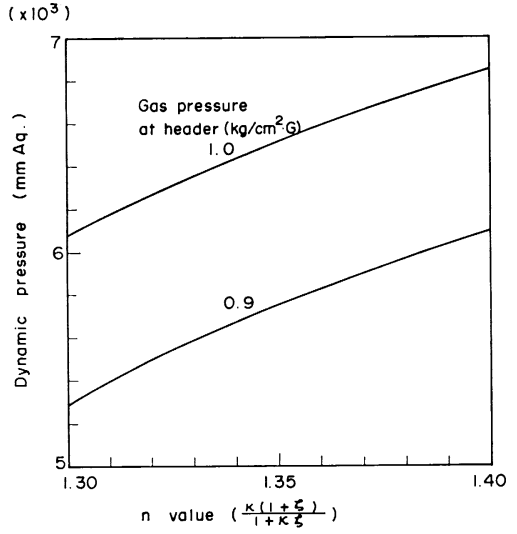

Fig. 16 Dependence of dynamic pressure in the critical region on $n$ value as a function of friction loss $\zeta$ (Gas : Air).

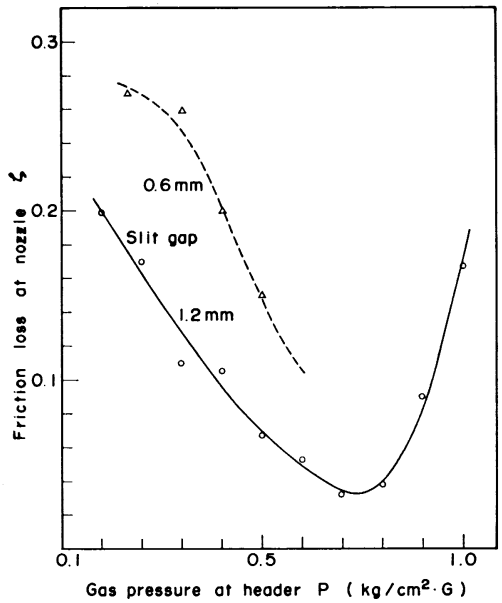

Fig. 17 Dependence of the friction loss at nozzle $\zeta$ on feed pressure $P$ for different slit gaps (Gas : Air).

$$
P_{\mathrm{cf}}=P\left(\frac{2}{n+1}\right)^{n / n-1}
$$

となり，これを(1)式一代入して臨界圧力時の流速 $w_{\mathrm{cf}}$ は

$$
w_{\mathrm{cf}}=\sqrt{\frac{2 \kappa}{\kappa-1} \cdot \frac{n-1}{n+1} \cdot \frac{P}{\rho}} .
$$

となる。(14)，(15)式をベルヌーイの式に適用して，n 值と動圧（览密には全圧一大気圧）の関係を求めたのが Fig. 16 である. 図より $n$ 值が求まるので，これより を得る。

Fig. 17 に上述の方法で求めたらのへッダー部ガス圧 力との関係を示した. 摩擦損失係数らはガス圧力の増加 とともに減少する.これは既述の境界層成長の理論から 説明できる．らは臨界圧力を生じる直前で最小值をと
り，以後増加傾向にあるが，これはガス密度の上昇によ り，流れのせん断応力 $\left(\left(\propto \rho w_{1}^{2}\right)\right.$ が増加するためであ ると推察される.

らはスリットギャップの大きさによつても異なる（ス リットギャップの小さいものの方がらは大きくなる) が， $1.2 \mathrm{~mm}$ のスリットギャップの場合では，その值は 最小部で約 0.03 ，低圧部では 0.2 にも達する。すなわ ち，運動量の $20 \%$ は摩擦によつて失なわれることにな るただしこの值には若干の動圧測定ロスが含まれてい ることを付け加えておく.

上述のように，スリットギャップは大きい方がより大 きな絞り力を得るためには効果的であり，高速めつき制 御に有利である。ただし，スリットギャップが増大した 場合には，それに比例して流量が増加するので，効率が 単純に増加するわけではない，ガス圧力を増強すれば， 小さなスリットギャップであつても絞り力は増加する が，Fig. 17 に見られるように臨界圧力をこえる場合に は摩擦損失が急激に増加する，以上からスリットギャッ プの選定にあたつては，製造ラインの能力を考え，最大 絞り力を要求されるときのガス圧力が臨界圧力をこえな いように設計することが望ましいと考えられる。

\section{6 その他付記すべき事項}

以上に述べてきたように，気体絞り付着量制御に関し ては概略の基礎メカニズムを理解できたと思われる，之 ころで，これまでの検討执よび考察の理論的根拠となつ ていたのは，溶融亜鉛あるいは絞りガス体の流れのあら ゆる条件下での均一性であり，相似性である。しかしな がら, 実際の操業では不均一性, 非相似性が重要な問題 になることがある．被めつき鋼帯の両端部でめつき厚さ が厚くなる (ェッジビルド) というのもこの 1 つの例で ある.エッジビルドに関する検討はこれまで多く報告さ れているが2) 4), 著者らも動圧分布の測定などにより， ノズル端部で動圧低下のないこと，および気体絞りを行 わない場合には特に両端部が厚くめつきされることのな いことなどを確認している.

エッジビルドの生じる原因は絞りとられる亜鉛が拘束 力の弱い両端に向けて流れるためとの説があるが， 3 次 元よどみ点流れを考えると，ガス体自体も鋼帯の両端部 に扮いて外側に向けて流れるため，めつき面に作用する 力は鋼帯中心部に比較して弱くなるので，これも有力な 要因のひとつとして付け加えたい.

\section{4. 結言}

本研究は CGL の気体絞り機構を調査するため, ノズ ルからの気体噴流の運動に注目して実験・検討を行つ 
た. 結果を要約すると以下のとおりである.

1 ) めつき付着量と諸制御因子間の定量的な関係を検 討し，以下に示す基礎的な付着量モデル式を誘導した.

$$
\begin{aligned}
& W=K_{0} P-K_{1} D^{K_{2}} V^{K_{3}} \exp \left(-\frac{K_{4}}{V}\right) \\
& \text { ここにW: めつき付着量 }\left[\mathrm{g} / \mathrm{m}^{2} \cdot \text { both sides }\right] \\
& P: \text { ガス圧力 }\left[\mathrm{kg} / \mathrm{cm}^{2} \cdot \mathrm{G}\right] \\
& D: \text { ノズル間隔 }[\mathrm{mm}] \\
& V: \text { ラインスピード }[\mathrm{m} / \mathrm{min}] \\
& K: \text { 正の定数 }
\end{aligned}
$$

上式をライン製造実験のデータと比較したところ, 誤差 の標準偏差は約 7\% であつた.主な䛊差要因としてはラ インスピード变化に伴ら流体亜鉛の運動量変化などが考 えられる.

2 ) 絞りガス体が異なる場合でも基本的な気体絞りメ カニズムは変化しない. しかし絞り力は異なり, 常温空 気と $250^{\circ} \mathrm{C}$ 蒸気との比較では前者の方が絞り力は大き い.これはノズル噴射における噴流の運動量損失が空 気〈水蒸気の関係にあることによると思われる.

3 ) 絞りカはスリットギャップの大小によつても変化 する. たとえば，スリットギャップが $1 / 2$ になつたと き，同じ絞り力を有するためには約 2 倍のガス圧力が必 要となる.これは噴流の動圧が低下するためであつて, この現象もノズル噴射の運動量損失によつて説明され る.

4) ノズル噴射における噴流の運動量損失はガス圧力 によつても変化する. $1.2 \mathrm{~mm}$ のスリットギャップを持 つノズルでは低圧時に約 $20 \%$ の運動量損失を有する が，この值は圧力の上昇とともに減少し，臨界圧力に達 する直前で約 $3 \%$ という最小值を示す. 臨界圧力をこえ る圧力領域では再び損失が増大するという傾向にあるの で, 純粋に効率的見地からは臨界圧力をこえることは望
ましくない。

5 ) エッジビルドの原因としては，絞りとられる亜鉛 が拘束力の弱い鋼帯両端に向けて流れるといら説がある が，さらに噴流そのものも両端部では測面方向に流れる ことを考えると，鋼带端部に働く力が中央部に比較して 弱くなる（よどみ点流れ）ので，これも有力な要因の 1 つとして加えたい。

\section{文 献}

1) $A$. Nikoleizig, $T$. Koots, $F$. Weber, and $M$. Espenhahn: Stahl u. Eisen, 98 (1978) 7, p. 336

2 ) 梅田昭三, 泰 和宣, 山口輝雄, 今井幸義, 江原 勝也：日立評論， 57 (1975) 5, p. 51

3 ) $U$. Cerboncini, et. al.: Metallurgia Ital., 64 (1972) 5, p. 237

4 ）征矢 昇，田伏健二：日新製鋼技報，37 (1977) p. 93

5 ) 森本磨瑳雄, 尾崎康二, 前原一雄, 小田機東, 安 藤成海：鉄と鋼，62 (1976) 4, p. 192

6 ) 岡本謙三, 三和 浩, 福岡嘉和: 日本鋼管技報, 56 (1972), p. 63

7 ) $J \cdot J$. Butler, D. J. Beam, and $J . C$. HawKINS : Iron Steel Eng., 47 (1970) 2, p. 77

8 ) L. PrandtL: 流れ学 (上), (1972), p. 115 [ ロナ社]

9 ) 粟野誠一ら：機械工学便覧改訂第 5 版（日本機械 学会編), (1968), 11-63〜65

10) L. PrandtL: 流れ学 (上), (1972), p. 243 [ ロナ社]

11）青木成文ら：伝熱工学資料改訂第 2 版（日本機械 学会編), (1966), p. 262

12) L. PRANdTL : 流れ学 (上), (1972), p. $202[$ 〔 ロナ社]

13) H.W. Liepmann and $A$. Roshro: 気体力学, (1960)，p. 347 [吉岡書店】 